\title{
STATE CRIME, STRUCTURAL VIOLENCE AND COVID-19
}

\author{
Neve Gordon and Penny Green
}

Three weeks after the COVID-19 outbreak, the Hungarian parliament conferred formidable executive powers on Prime Minister Viktor Orbán, allowing him to rule by decree (Guardian 2020). In Israel, Prime Minister Benjamin Netanyahu announced that surveillance tools developed by the secret services to monitor Palestinians in the occupied territories would be used to track citizens infected with coronavirus (Tidy 2020). Meanwhile, the Chilean government sent the military to public squares that had until recently been occupied by protesters, while in the Philippines police arrested over 40,000 people within the first 11 days of the country's lockdown on charges of violating quarantine policies (Gebrekidan 2020; Cheng 2020). These are worrying trends. While the introduction of emergency measures to address the global pandemic is undoubtedly necessary, such forms of intervention underscore how many governments have exploited the COVID-19 crisis to introduce measures that undermine democratic principles and violate the civil and political rights of both citizens and migrants. Such state crimes are characterised by government over-reach where the executive arm uses its powers to undercut basic freedoms.

Yet the crimes of government over-reach have, to a significant extent, been overshadowed by more structural and attritional forms of violence-less commonly understood as state crimes. We frame these largely structural crimes as products of government under-reach. Government under-reach, it is important to emphasise, should not be identified with the absence of government intervention. Rather, it denotes forms of intervention designed to implement certain kinds of deregulation and austerity measures that have led to the evisceration of welfare policies and the erosion of the social safety net. This, to be sure, is not a new phenomenon. Long before the outbreak of the COVID-19 emergency measures, cronyism and mass disinvestment in public services and infrastructure inhibited the human rights and life chances of millions.

Indeed, during these exceptional times emergency measures have not only been exploited to curtail civil rights and democratic freedoms, but they have also been

Neve Gordon, Queen Mary University of London.

Penny Green, Queen Mary University of London. 
used to undermine economic and social rights. Many governments (not least, the UK and US) have abdicated responsibility for delivering basic needs to their populations by using emergency measures to accelerate processes of deregulation and outsourcing, and by allowing officials to hand out large, and at times vast, amounts of tax-payer's money to corporations to fulfil tasks traditionally carried out by the public sector. In the name of political and economic expediency, oversight and accountability mechanisms have been bypassed, and governments across the globe have signed contracts without tenders or any form of public scrutiny, thus augmenting existing clientelist practices.

While the media has exposed the corrupt side of these business ventures, the articles in this special issue use COVID-19 as a springboard to interrogate their effects in order to uncover the relationship between structural violence and state crime. Looking beyond agent-driven crimes, the authors analyse the ways in which governments have responded to the pandemic to trace the link between historical and current state crimes, and to illustrate how the past bleeds into the present. Focusing on the persistence of certain social structures, all of the articles that follow highlight crimes emanating from government under-reach but critically they also reveal a dialectical relationship between these crimes and those deriving from government over-reach.

\section{Criminal Carelessness}

From personal protective equipment (PPE) to COVID-19 testing and to track and trace systems, corruption, cronyism and a deadly disregard for the vulnerable have informed many governments' responses to the pandemic. The UK, for example, has witnessed an extraordinary and increasingly well-documented litany of government corruption under the pandemic emergency provisions (Coronavirus Act 2020). As the Good Law Project notes:

[W] already know of three vast-and inexplicable-procurement contracts for PPE. $£ 108 \mathrm{~m}$ went to a tiny pest control company with net assets of $£ 18,000$, Pestfix. Another $£ 108 \mathrm{~m}$ went to a modestly sized confectioner in Northern Ireland, Clandeboye Agencies. And another contract, worth $£ 252 \mathrm{~m}$, was awarded to Ayanda, an opaque private fund owned through a tax haven. There is no evidence that ... these companies had previously had any experience in supplying PPE (2020a). ${ }^{1}$

In a similar vein, the Tory government offered the global health care corporation Randox almost half a billion pounds in contracts - without any competitionto supply COVID-19 testing kits. Randox, as George Monbiot reported in The Guardian, employs the former Conservative environment secretary Owen Paterson 
as one of their consultants, and pays him $£ 100,000$ a year for 200 hours of work (2020). ${ }^{2}$ In July, following a series of failures, the government withdrew Randox testing kits from the market on the grounds of likely inaccuracy.

Worse still is the scandal attached to the outsourcing and management of the UK's test and trace system led by former chief of mobile network Talk Talk and Conservative Peer Dido Harding. Some 35 organisations, the vast majority private contractors, have profited handsomely from the government's $£ 12$ billion provision for what turned out to be a chaotic and incompetent system. Indeed the Serco Group, the largest single beneficiary, was gifted a $£ 410$ million contract without competitive tendering, yet subcontracted the work because of its own lack of experience and delivered a botched system that has seriously delayed the country's ability to contain the virus. Notably the contract Serco signed with the government contains no penalty clause for the corporation's failure to fulfil its terms (Moboit 2020). While corrupt "direct awards" under the emergency legislation began with COVID-19-related procurements, they were quickly extended to non-COVID19-related contracts (The Good Law Project 2020b). ${ }^{3}$ Investigative work by the Good Law Project and other groups has documented in some detail the "special pathways" by which cronyism and clientelism, hallmarks of certain forms of capitalist criminal processes, have advanced the interests of private corporations at the expense of public health (The Good Law Project 2020c).

The UK's decision to curtail investment in the public sector while channelling the taxpayer's money to private corporations is, however, in no way unique. Daniel Bruce from Transparency International claims that "Brazil, the US, Slovenia, Bosnia and Romania are among the countries where lucrative contracts were awarded to the well connected, potentially to the detriment of those with more expertise" (Bruce 2020). In the US, for example, there have been various reports about the outsourcing of services to corporate providers closely linked to the Trump administration. Trump-connected lobbyists have received up to $\$ 10.5$ billion in coronavirus spending, while up to $\$ 273$ million was awarded to more than 100 companies owned or operated by major donors to Trump's election campaign (Mellman and Eisen 2020). A pattern thus emerges. Since the outbreak of the pandemic we have witnessed governments around the world gifting highly lucrative contracts to their corporate supporters who in turn have also failed to deliver the necessary services they were contracted to provide. Such corrupt ineptitude is a form of criminal profiteering and can be conceptualized as a mechanism of outsourcing violations (Gordon 2002).

Governments have defended their policies and decisions by claiming that if they had not acted quickly_-bypassing regular procedures - more people would have died. In this way, COVID-19 deaths became both a driving force and a justification for corrupt state-corporate crime. It is crucial, however, to underscore that criminal carelessness in such cases refers not only, or even primarily, to the 
corrupt state-corporate interactions described above. While journalists, researchers and human rights organisations have done outstanding work exposing the corrupt interactions between politicians and CEOs, the primary crime manifests itself in the economic and social effects of these schemes, and is predominantly propelled by the social and economic structures informing capitalist society. As governments execute policies that reflect these structures they perpetuate crimes against populations within their jurisdictions, whether or not the policies featured direct corrupt practices. This, in turn, has led to a contraction and deskilling of the public workforce while corporate control of public services and infrastructures has increased inequality and widened existing social hierarchies (Cummins 2018). Such forms of state and corporate collusion are designed to relinquish state responsibility over the basic needs of large segments of the population. The acceleration of death witnessed during the pandemic has only helped expose the effects of these processes (Gordon and Green 2020).

\section{State-Corporate Crime as Structural Violence}

The articles in this issue examine state responses to COVID-19 as a means to uncover structural violence and to demonstrate how such violence is embedded in socio-economic institutions and policies. As a result of structural violence, millions of people fail to meet even their most basic needs. Recognising that the violence produced in and through social structures is both a driving force and a manifestation of state crime is not always a simple matter. This criminality is rarely identified as such because crime continues to be generally perceived as a discrete act perpetrated by individuals and defined as criminal by law. Yet, in addition to the more overt agent-driven acts of state crimes such as genocide, torture and grand corruption we have, in recent decades, witnessed austerity measures that have starved the health system - and the social safety net more generally - of necessary basic resources. This kind of defunding is in line with a neoliberal agenda and, while not defined as criminal by state law, has led to mass human suffering and countless unnecessary deaths - particularly of disadvantaged people. State crimes, we claim, are human rights violations perpetrated by states through both over-reach and under-reach to advance organisational goals (Green and Ward 2004).

A decade ago, Rob Nixon maintained that the harmful effects of structural violence tend to manifest themselves gradually over time, precipitating "slow violence", which is protracted, attritional and less viscerally shocking than the violence perpetuated by social agents (2011). The gradual violence perpetrated against the Rohingya in Myanmar - initially through stigmatisation and the denial of access to education, livelihood and health care-was, for instance, effectively hidden from view (Green, MacManus and de la Cour Venning 2015). It was only after the 2017 
genocidal violence, carried out primarily by the military, that Myanmar's systemic crimes were widely exposed for the world to see. Similarly, the acceleration of death precipitated by COVID-19, while wreaking its own havoc, is also exposing a series of state crimes. It reveals how economic and social structures inform policy choices adopted both in the past and present and how these, in turn, propel state crime.

Even before the widespread granting of corrupt contracts made headlines, local newspapers in the worst-affected countries reported on domestic health services, providing countless graphs of government investment in health care infrastructures and personnel. In the UK, with only 2.5 hospital beds and 2.9 doctors per 1,000 people (compared with an OECD average of 5.4 and 3.4 respectively), the connection between Tory austerity policies - framed here as government underreach - and mounting COVID- deaths was immediately apparent (OECD 2020a and b). Austerity was seen to kill. Several months later, when the outsourced track and trace system proved to be completely inadequate and the testing that had been contracted to private companies failed to produce results in a timely fashion, it became clear that the state-corporate nexus was, at least in part, responsible for the UK's terribly high death toll.

David Friedrichs and Valeria Vegh Weis remind us in their article in this issue that critical criminology offers an especially potent framework for examining how the health care industry has dealt with the COVID-19 crisis (2021). They propose fostering a "critical health criminology" to analyse the relation between pharmaceutical conglomerates and the state in order to expose and analyse the detrimental impact these relations have on the population. Eve Darian-Smith develops this critical approach in her article as she invokes the concept "necroeconomy" to illustrate a particular feature of state-corporate crime by which profit flows from the precipitation of death (2021).

Darian-Smith begins by interrogating the pharmaceutical conglomerate Purdue, one of the largest opioid manufacturers, revealing how the corporation initially targeted white people living in extreme poverty in the former mill and mining towns of central Appalachia. By 2016, 11 million Americans misused prescription opioids and 2.1 million adults reported that they were addicted. In 2018, opioid overdoses killed 48,000 people, bringing the total death toll since 2000 to 400,000, a number greater than that of American combat deaths in the Second World War, Korean War and Vietnam War combined. Such "economies of death", DarianSmith claims, disavow the needs of people, who are either considered "replaceable" or are "unemployed and unemployable", and transforms them into "death subjects" (Haskaj 2018). She then draws a link between the opioid crisis and the pandemic in the United States, demonstrating how the economic system profits through the monetisation of death and killing and how the state is wrapped within this system and therefore fails to protect its own citizenry. 
The situation in the global south tends to be worse. Wide-scale exploitation of resources, political corruption, repression and poverty create an intensified vulnerability to natural disasters like earthquakes, floods and pandemics. The poor state of public health systems, which tend to be underfunded and lacking in adequate medicines, equipment and staff, is due to "the subordination of poorer countries to the interests of the world's wealthiest states and largest transnational corporations" (Hanieh 2020). In their contribution, Hilal Elver and Melissa Shapiro underscore this subordination in an acute analysis of the pandemic's effects on food system workers, who account for nearly one-third of the global workforce and comprise anywhere between 60 and 90 percent of the global "gig economy". Food system workers, they maintain, are trapped in structures of modern slavery characterised by persistent and severe human rights abuses. Such egregious violations persist, they argue, because the world's food system has been taken over by a handful of corporate actors that have converted economic wealth into direct political influence over government agenda setting (2021). It is important to bear in mind that specific forms of state regulation, rather than a lack of regulation, have enabled these corporations to accrue so much power and to deprive their workers of basic rights. By determining the degree and kind of regulation, the state shapes corporate influence and behaviour and is therefore complicit in corporate crimes.

While the processes Elver and Shapiro describe have existed for several decades, the pandemic seems to have aggravated a series of contradictions that informs the food supply chain. The closure of borders, for example, has precipitated labour shortages in the agricultural sector, which is likely, in turn, to engender a spike in food prices. Preliminary projections already suggest that an additional 83 to 132 million people may find themselves undernourished in 2021 . With 135 million people already on the threshold of hunger, there is a possibility that this number will increase to over 250 million. According to the World Food Programme president, 300,000 people may die every day due to the food crisis, with child mortality under the age of five rising by 6,000 deaths per day in the next six months.

COVID-19's devastating economic impact becomes strikingly clear when examining shortages within the food supply chain. These shortages have led states to issue emergency declarations confirming the "essential status" of food system workers in light of supply chain disruptions and a surge in food prices. Yet the solutions workers are offered undermine a series of protections, violating basic human rights. According to Elver and Shapiro, workers who harvest, process and distribute food are presented with an impossible choice: risk your life or risk your livelihood. This too is part of a necroeconomy, and it is therefore unsurprising that, according to a Center for Disease Control study, more than 200 outbreaks of COVID-19 have occurred at poultry, pork and beef processing plants in 
the US. Given what other articles in this issue reveal about the intersection between "economies of death" and race, it is also not surprising that people of colour are vastly over-represented in infection rates. Elver and Shapiro's article ultimately shows how government under-reach has helped facilitate corporate abuse of power and how this leads both to the violation of workers' rights and to the dramatic shortage in food supply, which is likely to kill hundreds of thousands if not millions of people.

A similar state-corporate alliance is analysed in Jose Atiles Osoria's contribution on Puerto Rico. Dissecting the government's relationship with the pharmaceutical industry operating on the island, Atiles Osoria argues that corrupt interactions are not simply a consequence of a specific rupture or disaster triggered by an earthquake or pandemic, but are in fact intrinsically embedded in traditional forms of colonial rule that have aligned with the dominant neoliberal ethos (2021). Tax holidays, cheap labour and little if any regulation have been used as incentives to attract corporate giants and, once on the island, these corporations have wielded immense power. Their obligations, moreover, are towards their shareholders in the metropole rather than to Puerto Rico's population, and often the way they operate and the decisions they make increase human suffering. COVID-19, according to Atiles Osoria, has not generated new relations of power, but has exposed how corporations have in effect replaced former colonial governments in what can be characterised as a neocolonial enterprise.

All three articles use the global pandemic as a lens to uncover how the economic and social processes of privatisation have empowered corporations that are concerned first and foremost with maximising profit margins. Using the state crime framework to conceptualise these processes helps the authors to reveal that they are neither natural nor inevitable. Yet these articles, as well as the others in this issue, suggest that if ending state crime is the objective, then it is crucial to understand the historical underpinnings of these structures as well as the relations of power they help sustain, produce and reinforce. Indeed, an examination of the way governments have responded to the pandemic helps uncover historic state crimes towards marginalised and oppressed groups, while illuminating that many of these crimes have never been adequately dealt with and therefore continue to haunt our present moment.

\section{Race and Class}

Although data is still limited, the early claim that COVID-19 was an equaliser, killing both the rich and poor, black and white was swiftly revealed to be false. This is nowhere clearer than in Laura Finley's article about the virus's impact on Native Americans (2021). The fact that indigenous people make up approximately 
one-tenth of New Mexico's population but represent more than 55 percent of its coronavirus cases and in Wyoming make up less than 3 percent of the population but one-third of positive cases cannot, she claims, be understood without excavating Native American history. Finley maintains that in order to explain the disproportionately high rates of positive cases among the indigenous population it is vital to take into account their over-representation in statistics on unemployment, food insecurity, deficient education and limited access to health care. In other words, one cannot understand the pandemic's impact without connecting it to the historic state crimes carried out against Native Americans. Like an earthquake that shatters a city, filling the streets with debris and leaving only the bare infrastructure exposed, COVID-19 has been uncovering some of the historic crimes that the United States has perpetuated against its indigenous population. Also like an earthquake, the destruction and death in the pandemic's wake are neither inevitable nor entirely natural (Green 2005).

Similarly, historical processes have to be analysed to understand why black Americans have experienced the highest COVID-19 mortality rates - more than twice the rate for whites and Asians. If they had died of COVID-19 at the same rate as white Americans, then at the time of writing (November 2020) approximately 21,800 black Americans would not have lost their lives to the virus (APM Research Lab 2020). It is precisely in this context that we read Elizabeth A. Bradshaw's article about how the U.S. COVID-19 crisis - with the world's highest number of positive cases and deaths - has intersected with its mass incarceration project. Highlighting the pandemic's racialised disparities, which have had the most profound effect on black and elderly prisoners, Bradshaw advances the concept of "state organised race crime" (2021). This, she shows, manifests itself in Michigan's correctional facilities where the pandemic has further exposed how American criminal law and health care system are infected and driven by systemic racism.

Bradshaw discusses how the elimination of any reduction in time served as a result good behaviour in Michigan has dramatically increased the size of the prison population while also producing a "graying" demographic group with significant pre-existing conditions. Pointing out that correctional facilities were never designed to be nursing homes equipped to serve the needs of an aging population, Bradshaw stresses the urgency of scaling up decarceration while imagining a world beyond state-organised violence where prisons no longer exist. Her analysis of Michigan's correctional facilities uses the pandemic as a catalyst to show how government over-reach has dramatically increased the prison population's size, and how governmental under-reach has led to the criminal neglect of these prisoners' basic needs.

The current plight of America's indigenous and black populations highlights what happens "when an acute crisis hits a chronic crisis", to employ a phrase 
advanced by Andrew Jefferson, Giorgio Caracciolo, Jeanette Kørner and Nina Nordberg in their article (2021). These authors describe how the pandemic has aggravated already existing deprivations, where in Uganda, for example, harsh lockdown enforcement has deepened the poverty of poor families suffering from food insecurity, while simultaneously criminalising dissent. The pandemic has not introduced new forms of policing as much as it has exposed the embeddedness of violence in existing policing practice. In essence, they write, the pandemic has reinforced and reproduced prevailing structures of precarity and vulnerability and these are sustained because the state both perpetuates and shields existing drivers of violence.

\section{Civil Society and the Challenge to "Free-Market Common Sense"}

The final article in this special issue analyses how "harms of the state" persist overtime. Roy Coleman suggests that oppressive structures can persevere due to the successful production of a "common sense" that both veils and promotes the perpetuation of harm. Invoking Antonio Gramsci's insights into hegemony and the production of common sense (1971), Coleman (2021) examines the conjuncture (Hall and Massey 2010) between the hegemonic "free-market common sense" and the pandemic, looking closely at how this common sense has helped shape the way the pandemic has been addressed, while also examining how the pandemic has generated a number of political schisms within the hegemonic worldview.

Tracing the historical emergence of a "free-market common sense", Coleman maintains that notions of "choice" and "freedom" have been tied to sentiments of national pride, and then demonstrates how such notions and sentiments have been mobilised against imagined enemies of a free-market utopia. Drawing a link between the Brexit debates in the UK and government responses to the pandemic, he describes how in both cases the public was urged to reject the recommendations provided by "experts" in favour of "freedom". In Brexit's case, freedom was associated with the "natural talents of the British people" hampered only by the overburdening state regulatory framework of the European Union, while in the case of COVID-19, freedom was associated with, inter alia, herd immunity and breaking lockdown rules, walking without a mask. If Brexit casts migrant workers as dispensable, the "free-market common sense" informing COVID-19 responses casts the elderly and the disabled as dispensable (McCoy 2020; Shimoni 2020). All other citizens were asked to "stay alert" because welfare, health and public safety are presented as matters of individual choice and responsibility rather than key duties of the state.

Government officials hoped that the "free-market common sense" of their policies would garner widespread support, but this time, as Coleman points out, schisms 
have become increasingly visible. Large sections of the public have been interested in what scientists have had to say, primarily because they believe that these experts are in fact defending their interests. Such ideological tensions, for example, played themselves out in the U.S. elections and had a decisive impact on President Donald Trump's defeat, and may also provide an opening for challenging the "free-market common sense". In the UK these same tensions have emerged as the government ignores its own scientific advisors, and may well create a similar opportunity for challenge as the death toll continues to rise (Sample 2020).

It is still too early to say exactly how the pandemic will impact the structures of violence affecting our lives in the longer term, and whether it will ultimately serve to increase or reduce state criminality. T. J. Coles has convincingly argued that in those states that effectively eradicated COVID-19 early in the pandemic, it was trust and cooperation between government, local authorities, scientists, health professionals and the public that was key (2020). It seems clear that if the lessons of the pandemic are to give rise to a concerted challenge to the unequal and deadly political and economic structures of capitalist society outlined above, our best means is through mass mobilisation of civil society. It could potentially force states to acknowledge and address the historical violence directed at marginal populations and it could propel a move towards reparations (Coates 2014) and redistribution (Piketty 2020), while also improving access to public goods by nationalising public services through a Green New Deal. Such a deal would enable states to create millions of new jobs to establish green networks and infrastructures by replacing fossil fuels with renewable energy (Pettifor 2020). These are the necessary stepping-stone for creating more caring economies and societies (Hakim, Chatzidakis, Littler, Rottenberg and Segal 2020). What the articles in this collection reveal so starkly is that the pandemic has not only helped expose underlying and largely hidden state crimes, but it has also created an opportunity for more caring societies. It is now up to civil society, given its pre-eminent role in defining, exposing and challenging state crime, to force states to make that change (Green and Ward 2019).

\section{Notes}

1. The investment company Ayanda specialises in "currency trading, offshore property and trade financing", yet was "direct awarded" its $£ 252$ million contract to produce facemasks — 50 million of which were deemed unusable. Ayanda has direct connections to the government and the award was facilitated by an advisor to the Board of Trade (chaired by Liz Truss, Secretary of State for International Trade) who is also a senior Ayanda board advisor.

2. Patterson is but one example of a pervasive phenomenon whereby government officials move to corporations (and vice versa), which is possible due to shared belief systems, ideology, tastes and worldview of the people occupying high places in these two worlds. 
3. In March 2020, Public First, a small privately held PR company (owned and directed by friends and colleagues of Cabinet Office Minister Michael Gove and Chief Advisor Dominic Cummings), was awarded $£ 840,000$ to manage the public relations around the government's A-level algorithm results fiasco. The government signed the contract without advertising or competitive tender.

\section{Bibliography}

APM Research Lab (2020) "The color of coronavirus: COVID-19 deaths by race and ethnicity in the U.S.”, 12 November. Available online at: www.apmresearchlab.org/covid/deaths-by-race (accessed 12 November 2020).

Bourdieu, P. (1990) The Logic of Practice. Stanford: Stanford University Press.

Bruce, D. (2020) "Corruption \& COVID-19: the story so far", Transparency International UK, 8 July. Available online at: www.transparency.org.uk/corruption-coronavirus-covid-19-latest (accessed 12 November 2020).

Cheng, M. (2020) “The Philippines”, International State Crime Initiative. Available online at: http:// statecrime.org/state-crime-research/covid19philippines (accessed 12 November).

Coates, T. N. (2014) “The case for reparations", The Atlantic, 313(5): 54-71.

Coles, T. J. (2020) Capitalism and Coronavirus. London: Ursa Major.

Coronavirus Act (2020). Available online at: www.legislation.gov.uk/ukpga/2020/7/contents (accessed 12 November 2020).

Cummins, I. (2018) Poverty, Inequality and Social Work: The Impact of Neo-liberalism and Austerity Politics on Welfare Provision. Bristol: Policy Press.

Gebrekidan, S. (2020) "For autocrats, and others, coronavirus is a chance to grab even more power", New York Times, 30 March. Available online at: www.nytimes.com/2020/03/30/world/europe/ coronavirus-governments-power.html (accessed 12 November 2020).

Geoghegan, P. (2020) "Cronyism and clientelism", 5 November. London Review of Books, 42(21). Available online at: www.lrb.co.uk/the-paper/v42/n21/peter-geoghegan/cronyism-and-clientelism (accessed 12 November 2020).

Good Law Project (2020a) "The PPE fiasco". Available online at: https://goodlawproject.org/case/ procurement-case/ (accessed 12 November 2020).

Good Law Project (2020b) "Money for Dominic Cummings' mates". Available online at: https:// goodlawproject.org/case/money-for-dominic-cummings-mates/ (accessed 12 November 2020).

Good Law Project (2020c) "Exposed: special procurement channels for 'VIPs' and Cabinet contacts", 29 October. Available online at: https:/goodlawproject.org/news/special-procurement-channels/ (accessed 12 November 2020).

Gordon, N. (2002) “Outsourcing violations: the Israeli case”, Journal of Human Rights, 1(3), pp.321-337.

Gordon, N., and Green, P. (2020) "The acceleration of death precipitated by Covid-19 exposes state crime", Open Democracy, 21 April. Available online at: www.opendemocracy.net/en/can-europemake-it/acceleration-death-precipitated-covid-19-exposes-state-crime/ (accessed 12 November 2020).

Gramsci, A. (1971) Selections from the Prison Notebooks, Hoare, Q. (trans.) London: Lawrence and Wishart.

Green, P. (2005) "Disaster by design: corruption, construction and catastrophe", British Journal of Criminology, 45(4): 528-546.

Green, P., Ward, T. (2004) State Crime: Governments, Violence and Corruption. London: Pluto Press. 
Green, P., Ward, T. (2019) State Crime and Civil Activism: On the Dialectics of Repression and Resistance. London: Routledge.

Green, P., MacManus, T. and de la Cour Venning, A. (2015) Countdown to Annihilation: Genocide in Myanmar. London: International State Crime Initiative.

Hakim, J., Chatzidakis, A., Littler, J., Rottenberg, C., Segal, L. (2020) The Care Manifesto: The Politics of Interdependence. London: Verso Books.

Hall, S., and Massey, D. (2010) "Interpreting the crisis", Soundings, 44 (Spring): 57-71.

Hanieh, A. (2020) “This is a global pandemic: let's treat it as such”, Verso Blog, 27 March. Available online at: www.versobooks.com/blogs/4623-this-is-a-global-pandemic-let-s-treat-it-as-such?fbcli d=IwAR3ebVUq5GhU11lccNcW-onojZ8RQgex2uAc1nIs5uCOexyXTKeyKGWwd0s (accessed 12 November 2020).

Haskaj, F. (2018) "From biopower to necroeconomies: neoliberalism, biopower and death economies", Philosophy \& Social Criticism, 44(10): 1148-1168.

McCoy, I. (2020) "Faith in coronavirus modelling is no substitute for sound political judgment", The Guardian, 10 April. Available online at: www.theguardian.com/commentisfree/2020/apr/10/ modelling-pandemic-politicians-decisions-science (accessed 12 November 2020).

Mellman, A., and Eisen, N. (2020) "Addressing the other COVID crisis: Corruption", The Brookings Institute, 22 July. Available online at: www.brookings.edu/research/addressing-the-other-covidcrisis-corruption (accessed 12 November 2020).

Monbiot, G. (2020) "The government's secretive Covid contracts are heaping misery on Britain", The Guardian, 6 October. Available online at: www.theguardian.com/commentisfree/2020/oct/21/ government-covid-contracts-britain-nhs-corporate-executives-test-and-tracePatterson (accessed 12 November 2020).

Nixon, R. (2011) Slow Violence and the Environmentalism of the Poor. Cambridge, MA: Harvard University Press.

OECD (2020a) "Hospital beds". Available online at: https://data.oecd.org/healtheqt/hospital-beds.htm (accessed 12 November 2020).

OECD (2020b) "Doctors". Available online at: https://data.oecd.org/healthres/doctors.htm (accessed 12 November 2020).

Pettifor, A. (2020) The Case for the Green New Deal. London: Verso.

Piketty, T. (2020). Capital and Ideology. Cambridge, MA: Harvard University Press.

Ratcliffe, R. (2020) "Teargas, beatings and bleach: the most extreme Covid-19 lockdown controls around the world", The Guardian, 1 April. Available online at www.theguardian.com/globaldevelopment/2020/apr/01/extreme-coronavirus-lockdown-controls-raise-fears-for-worlds-poorest (accessed 12 November 2020).

Sample, I. (2020) "Covid: ministers ignored Sage advice to impose lockdown or face catastrophe", The Guardian, 13 October. Available online at: www.theguardian.com/world/2020/oct/12/ministersrejected-four-out-five-proposals-from-sage-to-avert-covid-second-wave (accessed 12 November 2020).

Shimoni, S. (2020) "How coronavirus exposes the way we regard ageing and old people", The Conversation, 31 March. Available online at: https://theconversation.com/how-coronavirus-exposesthe-way-we-regard-ageing-and-old-people-135134 (accessed 12 November 2020).

Tidy, J. (2020) "Coronavirus: Israel enables emergency spy powers", BBC News, 17 March. Available online at: www.bbc.co.uk/news/technology-51930681 (accessed 12 November 2020). 